\title{
Technical parameters of high speed lines as the determinant for selection of rolling stock
}

\author{
Jan Raczyński ${ }^{1, *}$ \\ ${ }^{1}$ Research Railway Institute, ul. Chłopickiego 50, 04-275, Warsaw, Poland
}

\begin{abstract}
Choosing a high-speed rail vehicle depends on many factors. On the one hand, there are requirements for ensuring the quality of service for passengers, on the other hand, there are constraints resulting from the parameters of available infrastructure. Also a relation of the benefit and financial costs associated with the purchase and the operation of rolling stock is essential. Technical characteristics of vehicles selected for operating a particular system is a compromise between the three groups of requirements. In this article technical parameters of railway infrastructure and rolling stock are classified and then analysed from the TSI requirements point of view.
\end{abstract}

\section{Introduction}

Designing high-speed rail systems requires selection of technical parameters of new or planned for modernization of railway lines. Decisions on investing in railway infrastructure are determined by economic and social needs. These needs can be divided into two groups:

- getting the required travel time between specific regions;

- ensuring adequate transport capacity of a given line in scope of passenger and goods transport.

Technical parameters of high-speed lines result from many conditions: operational requirements, design assumptions as well as access to design solutions and technologies.

Train operation is associated with limitations resulting from the adoption of specific technical parameters for them. Rolling stock parameters are thus determined at the stage of line design.

Although in Europe both railway infrastructure managers and train operating companies are de facto independent entities, choosing new lines technical parameters should take into account the synergy effect. Therefore, the question arises how to make optimal decisions on both infrastructure and rolling stock investments from the operational and economic point of view.

\section{Travel time role}

In high-speed rail systems design the possibility of obtaining the shortest travel times is of particular importance.

The travel time assumed in the construction or modernization project results from forecasting assumptions for future transport. From the traveler's point of view, it is not important to know how fast he will travel, but at what time he will reach his destination. The volume of interurban travel is strongly dependent on travel time between certain cities or regions.

The influence of the journey time on the performance of passenger transport expressed both in number passengers and passenger-kilometres is much greater than ticket prices. In consequence in spite of higher ticket prices in high speed trains, the demand for transports is increasing along with shortening the journey time (Fig. 1). It is leading railways to the improvement in the competitiveness on the transport market, contributing from fulfilling purposes of the European transport politics and the strategy of the sustainable development of the transport [1]. It is also important factor of the improvement in the competitiveness of states and regions of the European Union [5].

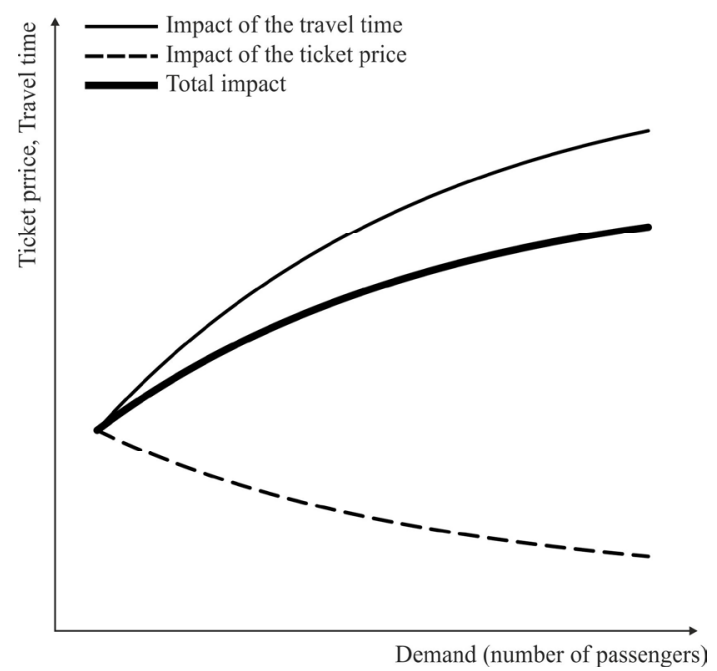

Fig. 1. Impact on the travel time and ticket price on demand in passenger transport. [2]

\footnotetext{
* Corresponding author: j.raczynski@infotransport.pl
} 
The optimal value of the travel time adoption results in the required technical parameters for a given line and, above all, the maximum speed that can be attained on it. It is obvious that the journey time should be the shortest. The choice of its value is a compromise between the forecasted effects and the costs incurred for the construction of the line.

Factors determining the travel time choice are as follows:

- Ensuring high transport accessibility of concerned regions, including travel time to the railway station. It is therefore a socio-economic factor and it may result from the internal state policy regarding the resources consolidation by obtaining synergy effects and ensuring the harmonious development of regions. In external policy, this objective may be used to strengthen the international position of a country linked to other countries by effective economic ties in which transport plays a key role.

- Provision of large passengers flows who decide to use rail transport as long as it is attractive in terms of speed and travel time. It is important not only to ensure high competitiveness of the railways in relation to other means of transport but also to generate new demand that would not have been created without a radical shortening of travel time in comparison to the one before the new line construction [6].

The longer is the travel time, the lower is the willingness of people to travel. Shortening the travel time increases the number of passengers. From the passenger's point of view, it is possible to separate certain time intervals determining his willingness to travel. It is assumed in transport forecasts that if travel times are no higher than 90 minutes, the railway shares in the transport market are very high and even exceeding $90 \%$. Shares decrease gradually until they drop significantly after exceeding 3 hours. Air transport is an important competitor in this period of time [7].

Table 1. Travel time and socio-economic effects and railway competitiveness [7].

\begin{tabular}{|l|l|l|l|}
\hline $\begin{array}{l}\text { Travel } \\
\text { time }\end{array}$ & $\begin{array}{l}\text { Socio-economic } \\
\text { effects }\end{array}$ & Passengers flows & $\begin{array}{l}\text { Railway } \\
\text { competitiveness }\end{array}$ \\
\hline $\begin{array}{l}\text { Up to 1,5 } \\
\text { hour }\end{array}$ & $\begin{array}{l}\text { An inter- } \\
\text { agglomeration job } \\
\text { and services } \\
\text { market is created } \\
\text { generating } \\
\text { economic growth }\end{array}$ & $\begin{array}{l}\text { Relatively high } \\
\text { and even } \\
\text { passenger flows } \\
\text { during the whole } \\
\text { day - possible } \\
\text { business travel on } \\
\text { different day time. }\end{array}$ & $\begin{array}{l}\text { Very high railway } \\
\text { competitiveness, } \\
\text { in some relations } \\
\text { unrivaled }\end{array}$ \\
\hline $\begin{array}{l}1,5-\text { about } \\
3 \text { hours }\end{array}$ & $\begin{array}{l}\text { Active, } \\
\text { multilateral } \\
\text { economic } \\
\text { connections are } \\
\text { created }\end{array}$ & $\begin{array}{l}\text { Possible one-day- } \\
\text { trip travel } \\
\text { particularly } \\
\text { important for } \\
\text { business. }\end{array}$ & $\begin{array}{l}\text { High railway } \\
\text { competitiveness. }\end{array}$ \\
\hline $\begin{array}{l}\text { Above 3 } \\
\text { hours }\end{array}$ & $\begin{array}{l}\text { Depending on } \\
\text { economic and } \\
\text { social relations, } \\
\text { friendly } \\
\text { conditions for } \\
\text { strengthening } \\
\text { socio-economic } \\
\text { links are created }\end{array}$ & $\begin{array}{l}\text { With the time } \\
\text { above 3 hours, the } \\
\text { possibility of } \\
\text { generated demand } \\
\text { drops }\end{array}$ & $\begin{array}{l}\text { The } \\
\text { competitiveness of } \\
\text { railways } \\
\text { decreasing after } \\
\text { exceeding 3 hours } \\
\text { to very small } \\
\text { market shares }\end{array}$ \\
\hline
\end{tabular}

- The possibility of reducing unit passenger transport costs calculated per passenger-kilometer. It is the lower as the shorter is the travel time, which is related to better use of production means, i.e. rolling stock and personnel. The only cost element that is increasing with the train speed is the electricity cost. The acceptability of higher energy costs results from compensating them by shortening the travel time, which is also an economic category and has a certain value for the traveler who is able to incur additional travel expenses for a certain service quality level.

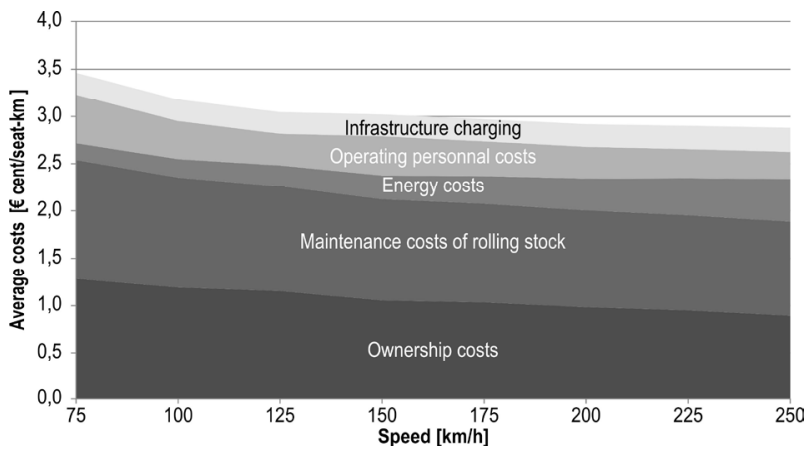

Fig. 2. The structure of the operator's average costs depending on the commercial speed of the train [3].

\section{Railway lines categories}

Classification of essential parameters for infrastructure and railway lines categorization is the subject of the EU TSI Infrastructure and other TSIs related to the design of railway lines:

- power supply (TSI ENE),

- safety in tunnels (SRT TSI),

- facilities for people with reduced mobility (PRS TSI),

- rail traffic control (CCS TSI) [4].

The TSI Infrastructure specification introduces the both passenger and freight traffic lines classification. Lines with mixed traffic are described by two categories for freight and passenger traffic.

In terms of requirements for travel time, the railway line maximum speed is a crucial parameter for achieving the goal. This especially applies to long-distance traffic.

The railway line capacity depends on the load and length of the trains. The three most important parameters that characterize them are the gauge, the permissible axle load and the station tracks length, or in the case of passenger transport - the length of the platforms.

The generally accepted criterion for railway lines classification as a high-speed is the possibility of its operation at a speed of at least $250 \mathrm{~km} / \mathrm{h}$. EU legislation has introduced a category of lines with a speed of less than $250 \mathrm{~km} / \mathrm{h}$ for high-speed supplementary lines i.e. feeders or modernized lines, for which reaching a speed of at least $250 \mathrm{~km} / \mathrm{h}$ due to various objective factors was not possible. The basic parameters for these two lines categories are shown in Table 1. 
Table 2. Operating parameters for passenger lines with speeds above $200 \mathrm{~km} / \mathrm{h} \mathrm{[4].}$

\begin{tabular}{|l|l|l|l|l|}
\hline $\begin{array}{l}\text { Traffic } \\
\text { code }\end{array}$ & Gauge & $\begin{array}{l}\text { Axle } \\
\text { load }[\mathrm{t}]\end{array}$ & $\begin{array}{l}\text { Speed } \\
{[\mathrm{km} / \text { hour }]}\end{array}$ & $\begin{array}{l}\text { Platform } \\
\text { length }[\mathrm{m}]\end{array}$ \\
\hline P1 & GC & 17 & $250-350$ & 400 \\
\hline P2 & GB & 20 & $200-250$ & $200-400$ \\
\hline
\end{tabular}

The parameters ,gauge" and ,,axle load" are treated as minimum requirements. The „line speed”, „platform length" and ,train length" columns indicate the range of values that are typically used for different traffic types and do not directly impose restrictions on traffic on a given line. It is also acceptable to design new and modernized lines, which will be adapted to larger gauges, higher axle loads, higher speeds, longer platform lengths and longer trains than specified above.

The railway line is also characterized by parameters resulting from the vehicle power supply system. The requirements are described in the ENI TSI. For high speed lines, in Europe are used two AC systems: $25 \mathrm{kV} 50 \mathrm{~Hz}$ and $15 \mathrm{kV} 16.6 \mathrm{~Hz}$. For P2 lines category, a $3 \mathrm{kV}$ DC power supply system is also acceptable, but the economic and energy efficiency of which is lower than for AC systems. The power system determines the power consumed by the trains and the same maximum speed and trains mass.

\section{Travel time and maximum speed}

From the point of view of railway infrastructure the shorter travel times is as the higher maximum speed is. Her choice is determined by several factors, the most important of which are:

- expected journey time;

- terrain conditions;

- line construction cost;

- technical solutions availability.

The line maximum speed is strongly determined by topographical conditions. High maximum speed requires increasing the railway track curves radius. It is not difficult to implement in a flat and thin area. For such conditions, differences between costs of the 160 to 350 $\mathrm{km} / \mathrm{h}$ line are small. In difficult topographic conditions, i.e. in mountain areas, the costs of increasing speed are higher. For this reason, in such specific cases lines are designed for up to $250 \mathrm{~km} / \mathrm{h}$ speed. (Switzerland, Basque Country, Belgian Ardennes region).

Currently in Europe, new lines are built or designed at maximum speeds in the range of $300-350 \mathrm{~km} / \mathrm{h}$, less often at $250 \mathrm{~km} / \mathrm{h}$. A summary of maximum speeds for Europe is presented in table 3. Larger maximum speeds are used or planned in China, mainly due to the large distances between agglomerations.

When assessing the impact on the travel time of the maximum speed increase a simplified analysis can be used. It compares time differences for different maximum speeds on 100, 200 and $300 \mathrm{~km}$ line sections without train stops.

For actual operating conditions in analyzes should be used a commercial speed, depending on many factors, including:
- the number of stops at intermediate stations

- time needed for departures from railway junctions, usually at a lower speed

Table 3. Maximum new line speeds in Europe.

\begin{tabular}{|c|c|c|}
\hline Country & $\begin{array}{c}\text { Maximum design } \\
\text { speed for new lines } \\
{[\mathrm{km} / \mathrm{h}]}\end{array}$ & $\begin{array}{l}\text { Length of a railway line } \\
\text { operated, built or planned } \\
{[\mathrm{km}]}\end{array}$ \\
\hline Austria & 250 & 266 \\
\hline Czechia & $300-350$ & 890 \\
\hline Denmark & 250 & 206 \\
\hline Estonia & \multirow{3}{*}{250} & \multirow{3}{*}{870} \\
\hline Latvia & & \\
\hline Lithuania & & \\
\hline France & $320-350$ & 4562 \\
\hline Germany & $250-300$ & 2167 \\
\hline Italy & $250-300$ & 1269 \\
\hline Poland & $300-350$ & 1305 \\
\hline Portugal & 300 & 596 \\
\hline Spain & $250-350$ & 4903 \\
\hline Sweden & 320 & 740 \\
\hline UK & 400 & 656 \\
\hline Switzerland & 250 & 159 \\
\hline Russia & 400 & 2978 \\
\hline
\end{tabular}

Source: UIC Statistics (2017)

Table 4. Travel time as a function of the maximum speed.

\begin{tabular}{|l|c|c|c|}
\hline \multirow{2}{*}{$\begin{array}{l}\text { Maximum } \\
\text { speed }[\mathrm{km}]\end{array}$} & \multicolumn{3}{|c|}{ Section length $[\mathrm{km}]$} \\
\cline { 2 - 4 } & 100 & 200 & 300 \\
\hline 200 & 30 & 60 & 90 \\
\hline 250 & 24 & 48 & 72 \\
\hline 300 & 20 & 40 & 60 \\
\hline 350 & 17 & 34 & 51 \\
\hline 400 & 15 & 30 & 45 \\
\hline
\end{tabular}

Own work.

For this reason, already at the design phase should be chosen solutions, like the maximum speed. Travel time depends on the track system, the way of servicing passenger stations or the existence of local speed limits. The travel time is also dependent on the solutions of track systems, The ratio of commercial speed to the maximum one on existing and planned lines can reach values even above 0.9 , but it is usually lower.

\section{Rolling stock parameters}

Selected rolling stock should allow maximum use of line parameters both in terms of ensuring the shortest travel time and capacity. Given in table 4 travel times are possible to get under theoretical conditions when the train goes at the line maximum speed and its acceleration and braking are equal to zero.

The essential rolling stock parameters that help to achieve the shortest transit time are as follows:

1. Maximum speed

Usually chosen to make use of the highest maximum speed sections. Currently, on the European market there are available vehicles with maximum speed from 320 to $350 \mathrm{~km} / \mathrm{h}$ but up to $400 \mathrm{~km} / \mathrm{h}$ speed is also possible.

2. Acceleration and deceleration 
These are parameters that are important when the distances between stations are small equal to several dozen kilometres. High acceleration and deceleration values are achievable with a large number of drive axles at the vehicle construction stage. However, this requires higher power supply efficiency.

3. Passenger flows

In order to ensure the shortest possible train stop time at the station, the interior layout and vehicle doors (their width and number) should allow passengers moving quickly and getting in and out.

4. Power supply

High speed lines of maximum speeds above $200-250$ $\mathrm{km} / \mathrm{h}$ are electrified with $25 \mathrm{kV}$, less often $15 \mathrm{kV}$ AC. AC systems are cheaper to build and are characterized by lower operating costs, primarily due to higher efficiency and lower energy losses on energy transmission. In addition, only they are capable of delivering high power to the vehicle, which at the highest speeds and long train sets reach values up to $20 \mathrm{MW}$.

Rolling stock capacity is defined by passenger seats number in vehicle and depends on the following parameters:

1. Train length

Due to the infrastructure characteristic his parameter should not exceed $400 \mathrm{~m}$. For P2 lines and lower platform lengths, it may be even smaller. For this reason, the standard length of the high-speed train is $200 \mathrm{~m}$. If the technical conditions allow it, trains can be combined in multiple traction.

\section{Vehicle gauge}

Larger wagons dimensions allow you to fit more seats in one row. In European conditions, due to historical requirements, it is not possible to use rolling stock with a gauge larger than that included in the GC infrastructure gauge.

\section{Axle load}

Increasing the capacity of trains is also possible through the use of double-deck structures. However, this causes an increase in the weight of the train and thus an increase in the weight per axle. Small axle loads are required due to the reduction of the dynamic impact of the vehicle on the track. The higher is the maximum speed, the lower the permissible axle loads. The trains with highest maximum speeds have axle loads of 17 tonnes and in the P2 category up to 20 tonnes per axle. This excludes the possibility of using locomotives for trains of a maximum speed above $200 \mathrm{~km} / \mathrm{h}$.

\section{Summary}

Operational requirements for high-speed rail systems determine the selection of technical parameters of railway lines and rolling stock for its service. In case of new line design, the correlation of these parameters can be made at the stage of feasibility studies. When designing railway line, forecasted future new technologies development should also be taken into account. Development trends in the rolling stock construction should be considering while choosing the maximum speed of the railway line. In general, it should be as high as possible. Current technologies allow the track, power supply and traffic safety systems construction adapted for the speed up to $400 \mathrm{~km} / \mathrm{h}$. For technical and cost reasons in difficult mountain conditions the line maximum speed can be limited to $250 \mathrm{~km} / \mathrm{h}$.

Even if currently maximum European rolling stock speed vary between 250 and $320 \mathrm{~km} / \mathrm{h}$ it should be taken into account that intensive work on new vehicle designs capable of reaching speeds of up to $400 \mathrm{~km} / \mathrm{h}$ is underway. In 2017, units with $350 \mathrm{~km} / \mathrm{h}$ maximum speed were put into operation in China and, ultimately, the construction of them enables running up to $400 \mathrm{~km} / \mathrm{h}$.

The choice of the maximum speed should also take into account the effects that can be obtained along with shortening the travel time, i.e. increasing the number of passengers and reducing unit costs for train operating companies, calculated per passenger kilometre.

Analysing European experiences, i.e. average distances between stations, it can be concluded that the optimal maximum velocity values are in the range of 300 $-350 \mathrm{~km} / \mathrm{h}$.

In case of choosing rolling stock for existing lines there are restrictions related to infrastructure parameters. In order to get better travel time for a defined maximum speed it is possible to choose rolling stock of higher acceleration value. In case of the necessity to improve train capacity infrastructural constraints are a bigger barrier, e.g. in terms of platforms length, which can be bypassed by the use of a double-deck rolling stock.

Table 5. Relation between infrastructure and high-speed rolling stock requirements.

\begin{tabular}{|l|l|l|}
\hline $\begin{array}{l}\text { Operation } \\
\text { requirements }\end{array}$ & Line parameters & $\begin{array}{l}\text { Rolling stock } \\
\text { parameters }\end{array}$ \\
\hline $\begin{array}{l}\text { Short travel } \\
\text { time }\end{array}$ & Maximum speed & $\begin{array}{l}\text { Maximum speed } \\
\text { Acceleration } \\
\text { Deceleration } \\
\text { Passenger flows }\end{array}$ \\
\cline { 2 - 3 } & $\begin{array}{l}\text { Power supply } \\
\text { efficiency }\end{array}$ & $\begin{array}{l}\text { Power drawn by } \\
\text { the train }\end{array}$ \\
\hline $\begin{array}{l}\text { Sufficiently } \\
\text { high transport } \\
\text { capacity }\end{array}$ & Platform length & Train length \\
\cline { 2 - 3 } & Structure gauge & $\begin{array}{l}\text { Rolling stock } \\
\text { length }\end{array}$ \\
\cline { 2 - 3 } & Axle load & Vehicle mass \\
\hline
\end{tabular}

\section{References}

[1] T. Dyr, and K. Ziółkowska, Economic infrastructure as factor of the region's competitiveness. Central European Review of Economics \& Finance, 6(3), (2014)

[2] T. Dyr, and K. Ziółkowska, Efektywność kolei dużych prędkości [w:] Siergiejczyk M. (red.), Koleje Dużych Prędkości w Polsce (Wydawnictwo Instytutu Kolejnictwa, Warszawa, 2015)

[3] T. Dyr, and K. Ziolkowska, Financial effectiveness of high speed railway in Poland, Technology Transport Systems [Technika Transportu Szynowego], 6 (2015) 
[4] Dziennik Urzędowy Unii Europejskiej L 356, Tom 57, 17 grudnia 2014.

[5] V. Maráková, T. Dyr, and A. Wolak-Tuzimek, Factors of tourism's competitiveness in the European union countries, E a M: Ekonomie a Management, 19(3) (2016) doi: 10.15240/tul/001/2016-3-007.

[6] Pedro Miguel Cardoso, Martins Network Manager, Eurocontrol statfor high-speed train model recalibration forecasting air transport workshop, (7th October, Cologne 2016)

[7] A. Szarata, and J. Raczyński, Analiza symulacyjna wielkości przewozów dla kolei dużych prędkości $w$ Polsce. Technology Transport Systems [Technika Transportu Szynowego], 6 (2017) 